\title{
Caesarean hysterectomy in a patient with placenta accreta spectrum disorders
}

\author{
Brahmana Askandar Tjokroprawiro (1)
}

Department of Obstetrics and Gynecology, Fakultas Kedokteran Universitas Airlangga, Surabaya, Indonesia

\section{Correspondence to} Dr Brahmana Askandar Tjokroprawiro;

brahmanaaskandar@gmail.com

Accepted 2 March 2021

\section{DESCRIPTION}

Placenta accreta spectrum (PAS) disorders is the abnormal invasion of the placenta to the myometrium. ${ }^{1}$ One of the risk factors of PAS is a previous caesarean section. ${ }^{2}$ Only few studies described caesarean hysterectomy in patients with PAS with images. We report a case of a caesarean hysterectomy in a 37-year-old pregnant woman previously diagnosed with PAS who visited the outpatient clinic at 31 weeks of gestation. The patient had undergone two previous caesarean sections. Ultrasonography showed total placenta previa with a high suspicion of PAS. She had no history of bleeding during prenatal care. When the patient reached term, she underwent a caesarean section with a hysterectomy. A midline incision was made for broader access. The lower segment of the uterus presented an atypical vascular pattern representing PAS (figure 1). A classical uterine incision was made to avoid the area, which presented an atypical vascular pattern. After the baby was delivered, the placenta was left in situ as the separation of the placenta from the uterus could have induced bleeding; this is the preferred management for PAS. ${ }^{2}$ Thus, caesarean hysterectomy was planned for this patient, and written informed consent was obtained prior to the surgical procedure.

Before continuing with hysterectomy, the uterine wall was closed to minimise bleeding (figure 2). Thereafter, hysterectomy was performed and the specimen (figure 3 ) was sent to the pathology laboratory. Pathological examination of the uterus confirmed the diagnosis of PAS and showed that the placenta penetrated into the myometrium but not into the serosa of the uterus. The operative time was $70 \mathrm{~min}$ with a blood loss of $2000 \mathrm{~mL}$, and the patient's postoperative haemoglobin level was $8.8 \mathrm{~g} /$

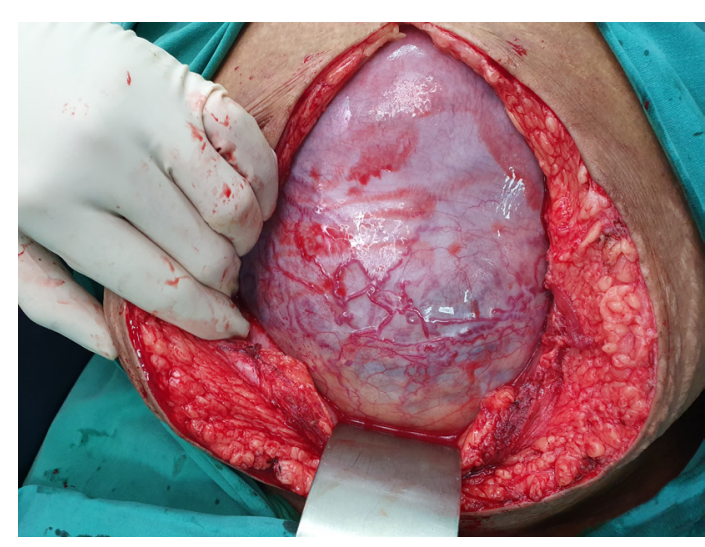

Figure 1 A midline incision of the skin was performed, The lower segment of the uterus presented an atypical vascular pattern.

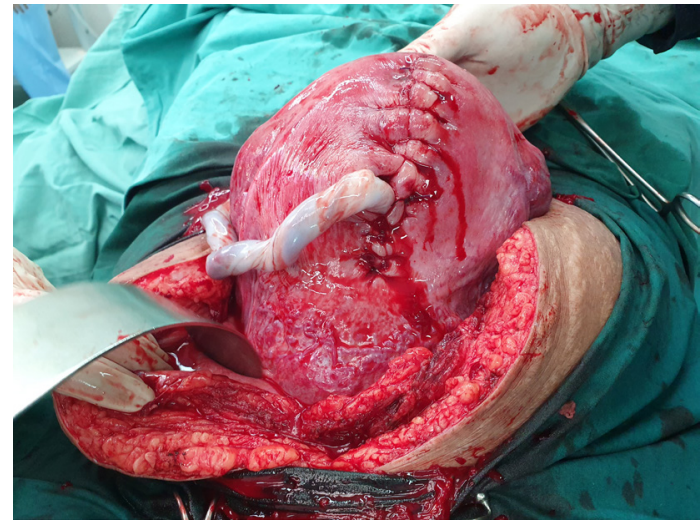

Figure 2 After the baby was delivered, the placenta was left in situ and uterine wall closure was performed before hysterectomy.

dL (preoperative haemoglobin level: $11.5 \mathrm{~g} / \mathrm{dL}$ ). The patient did not require a blood transfusion, and she was discharged in good condition 4 days postoperatively. The patient's newborn was healthy.

The atypical vascular pattern of the uterus representing PAS is important for clinicians to have knowledge about, especially when handling referral patients, because the antenatal care history of the patients is unknown. This situation may occur in developing countries where an integrated national medical record is not established. If clinicians from a small hospital observe an atypical vascular pattern

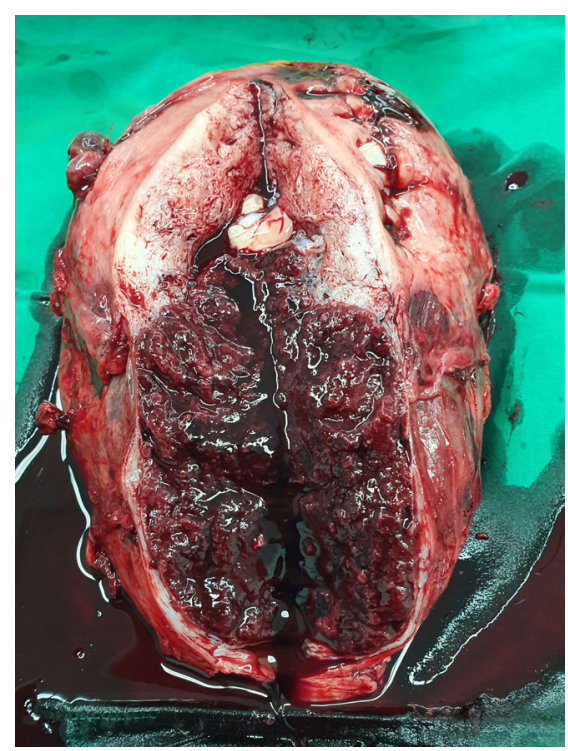

Figure 3 The uterus was sent for pathological examination, which confirmed the diagnosis of placenta accreta spectrum disorders. 


\section{Patient's perspective}

Cases of placenta accreta spectrum disorders should be managed in a tertiary hospital, where appropriate facilities/ medical devices and experienced specialists are available, so that women with conditions similar to mine and their babies will be safe.

\section{Learning points}

Previous caesarean section is a risk factor for placenta accreta spectrum (PAS) disorders.

- Atypical vascular pattern in the lower segment of the uterus is a sign of PAS disorders, and the incision for caesarean section should not be made in this area to prevent bleeding from the placenta.

- Closure of the uterine wall should be performed before hysterectomy to minimise bleeding, and caesarean hysterectomy must be performed with placenta in situ. in the lower segment of the uterus during a caesarean section, the abdomen should be closed, and the patient should be referred to a tertiary hospital if the delivery of the baby can be postponed.

Acknowledgements Dr Faroek Hoesin for histopathological examination.

Contributors BAT: Conceptualisation, drafting and editing.

Funding The authors have not declared a specific grant for this research from any funding agency in the public, commercial or not-for-profit sectors.

Competing interests None declared.

Patient consent for publication Obtained.

Provenance and peer review Not commissioned; externally peer-reviewed.

\section{ORCID iD}

Brahmana Askandar Tjokroprawiro http://orcid.org/0000-0003-1658-3477

\section{REFERENCES}

1 Jauniaux E, Ayres-de-Campos D, Langhoff-Roos J, et al. FIGO classification for the clinical diagnosis of placenta accreta spectrum disorders. Int I Gynaecol Obstet 2019;146:20-4.

2 Jauniaux E, Alfirevic Z, Bhide AG, et al. Placenta praevia and placenta accreta: diagnosis and management: Green-top guideline No. 27a. BJOG 2019;126:e1-48.

Copyright 2021 BMJ Publishing Group. All rights reserved. For permission to reuse any of this content visit

https://www.bmj.com/company/products-services/rights-and-licensing/permissions/

BMJ Case Report Fellows may re-use this article for personal use and teaching without any further permission.

Become a Fellow of BMJ Case Reports today and you can:

- Submit as many cases as you like

- Enjoy fast sympathetic peer review and rapid publication of accepted articles

- Access all the published articles

- Re-use any of the published material for personal use and teaching without further permission

Customer Service

If you have any further queries about your subscription, please contact our customer services team on +44 (0) 2071111105 or via email at support@bmj.com.

Visit casereports.bmj.com for more articles like this and to become a Fellow 